\title{
Composition and distribution of the European green crab in Prince Edward Island, Canada
}

\author{
Mary A. McNiven ${ }^{1 *}$, Pedro A. Quijon ${ }^{2}$, Alfred W. Mitchell ${ }^{1}$, Aaron Ramsey $^{3}$, Sophie St-Hilaire ${ }^{1}$

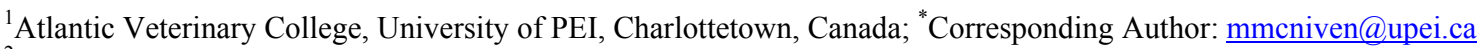 \\ ${ }^{2}$ Deptartment of Biology, University of PEI, Charlottetown, Canada \\ ${ }^{3}$ PEI Department of Fisheries, Aquaculture \& Rural Development, Montague, Canada
}

Received 25 July 2013; revised 26 August 2013; accepted 15 September 2013

Copyright (C) 2013 Mary A. McNiven et al. This is an open access article distributed under the Creative Commons Attribution License, which permits unrestricted use, distribution, and reproduction in any medium, provided the original work is properly cited.

\begin{abstract}
The European green crab (Carcinusmaenas) is a non-native invasive species to North America which has been found in the north-western Atlantic Ocean since the nineteenth century. In Prince Edward Island Canada, this species has been steadily increasing over the last 10 years, especially in estuaries found on the eastern and southern coasts. Our chemical analysis of the whole green crab determined that it was high in protein and ash, and low in lipid content. We also found the chemical composition varied only slightly for different sized crabs (40 to $70 \mathrm{~mm}$ ) over the six-month sampling period, suggesting this species could be harvested any time between May and October.
\end{abstract}

Keywords: European Green Crab; Catch Per Day; Chemical Analysis; Invasive Species

\section{INTRODUCTION}

The European green crab (Carcinusmaenas) is a nonnative invasive species to North America which has been found in the north-western Atlantic Ocean since the nineteenth century [1]. The green crab has flourished in North America because it is able to tolerate a wide range of water temperatures and salinities and live in many types of marine habitats [2]. This species of crab is a voracious predator that feeds on a variety of prey including soft shell clams, quahogs, mussels, and oysters $[3,4]$. In addition, the green crab competes with other crustaceans for nutrient resources and habitat $[5,6]$, and damages the ecosystem by digging in sediment around eelgrass beds and disturbing the root systems $[7,8]$.

Culling efforts to control this invasive species have not been successful to date likely because the efforts were not sustained, or due to the difficulty in removing all life stages of the crab by trapping [4,9]. An effective control of green crab populations on the east coast of Canada will require intensive trapping over a large spatial scale for a period of several years. From an economic point of view, this is not feasible unless potential uses for this species are identified and the crab can indeed be sold to subsidize or cover the cost of fishing. Unfortunately, there is currently no market for the European green crab in North America although it is a popular food in southern Europe [9]. It is a relatively small crustacean and although there is an ample supply, it is difficult to economically extract the meat so it has not been successfully marketed in North America.

As crustacean meat extraction technology improves and its cost decreases, it may be possible to identify markets for this species. For instance, green crab meat may be sold for human consumption [10] or be used as a paste for flavouring in soups, sauces and dips [11], which would utilize the whole crab eliminating the cost of meat extraction. It may also be possible to develop non-human food markets such as the pet or zoo food industry, the aquaculture feed industry, or as bait for commercial fisheries. The potential use of a species for these or other markets requires information such as body chemical composition and the distribution of harvestable populations, none of which is readily available for green crab.

The chemical composition of marine species destined for human consumption is influenced by nutritional preferences, age, sex, seawater temperature and salinity $[12,13]$. For this reason, it is important to document how the chemical composition of green crab changes over the course of the season when this species could potentially be harvested. In addition to the consistency of product quality, commercial markets require a constant (seasonal) supply of substantial quantities of crab for which harvestable areas must be identified. Hence, the objectives of our study were to assess the chemical composition of 
the European green crab over a six-month period and to estimate the distribution of these populations around Prince Edward Island (PEI), Canada.

\section{METHODS}

\subsection{Chemical Composition over Time}

In order to assess potential temporal changes, green crabs were captured in estuaries in eastern PEI on a monthly basis from May to October 2012 by deploying five Fukui traps in habitats known to contain green crabs. Traps were baited with approximately $100 \mathrm{~g}$ of mackerel. After collection, crabs were transported in coolers to the University of Prince Edward Island, where they were frozen at $-20^{\circ} \mathrm{C}$ until chemical analysis was done. All animal procedures were done in accordance with the Canadian Council of Animal Care.

Crabs were sorted by carapace size based on the categories most likely to be fished $(40-50 \mathrm{~mm}, 50-60 \mathrm{~mm}$, or $60-70 \mathrm{~mm}$ ). Samples of crabs were prepared by thawing the samples overnight. The pooled samples of crabs (five crabs/sample, three replicate samples) were weighed and dried in an oven at $60^{\circ} \mathrm{C}$ until the weight remained constant ( $\sim 72 \mathrm{~h})$. Samples were reweighed and ground using a centrifugal grinder (Retsch, ZM100) with a $1 \mathrm{~mm}$ screen. Samples were analyzed for dry matter, ash, nitrogen, and lipid as described by AOAC procedures [14]. All reagents were of analytical grade (Fisher Scientific, Ottawa, ON, Canada). The proportions of true protein and chitin were estimated using equations based on the nitrogen stoichiometric content of chitin and protein and the measured percentage values of total nitrogen and non-nitrogen compounds [15]. Results were analyzed using a two-way analysis of variance with month of capture and carapace size as the main effects [16]. Differences between means with a $\mathrm{P}$ value less than 0.05 were considered to be significant.

\subsection{Assessment of Harvestable Populations}

In order to document the spatial distribution of potentially harvestable populations, the most recent data from the PEI Department of Fisheries, Aquaculture, and Rural Development [17] was compiled and analyzed to estimate catch per unit effort (CPUE). Data came from samples collected with sets of three cylindrical $61 \times 38 \mathrm{~cm}$ coated wire mesh traps with a $5 \mathrm{~cm}$ catch opening at 27 sites around PEI between late August and mid October 2012. Traps were placed overnight in estuarine areas 1.5 to $2.5 \mathrm{~m}$ deep using herring as bait. Total number of crabs caught after a three day period was used to calculate CPUE (catch per trap per day).

\section{RESULTS}

\subsection{Chemical Composition}

The actual levels of ash, lipid, and total nitrogen as well as estimated true protein and chitin levels of green crabs based on carapace size and month of harvest are shown in Table 1. In general, differences in composition

Table 1. Chemical composition of whole green crab samples (50 - $70 \mathrm{~mm}$ carapace width) collected once per month from May to October 2012. (Means within column and month with different superscripts are significantly different, $\mathrm{P}<0.05$ ).

\begin{tabular}{|c|c|c|c|c|c|c|}
\hline & Carapace mm & Ash \% DM & Lipid \% DM & Nitrogen \% DM & Protein (est.) \% DM & Chitin (est.) \% DM \\
\hline \multirow{3}{*}{ May } & 40 & $32.9^{\mathrm{c}}$ & $4.67^{\mathrm{a}}$ & $5.98^{\mathrm{a}}$ & $18.4^{\mathrm{a}}$ & 44.0 \\
\hline & 50 & $36.1^{\mathrm{b}}$ & $3.43^{\mathrm{b}}$ & $5.63^{\mathrm{ab}}$ & $16.0^{\mathrm{b}}$ & 44.5 \\
\hline & 60 & $38.0^{\mathrm{c}}$ & $3.23^{\mathrm{b}}$ & $5.04^{\mathrm{b}}$ & $14.8^{\mathrm{b}}$ & 43.9 \\
\hline \multirow{3}{*}{ June } & 40 & $34.3^{\mathrm{b}}$ & $4.15^{\mathrm{a}}$ & $5.66^{\mathrm{a}}$ & $15.6^{\mathrm{a}}$ & $45.9^{\mathrm{b}}$ \\
\hline & 50 & $38.2^{\mathrm{a}}$ & $3.11^{\mathrm{b}}$ & $5.25^{\mathrm{b}}$ & $13.2^{\mathrm{a}}$ & $45.5^{\mathrm{b}}$ \\
\hline & 60 & $39.5^{\mathrm{a}}$ & $2.71^{\mathrm{b}}$ & $4.75^{\mathrm{c}}$ & $8.44^{\mathrm{b}}$ & $49.3^{\mathrm{a}}$ \\
\hline \multirow{3}{*}{ July } & 40 & $37.9^{\mathrm{b}}$ & $2.69^{\mathrm{a}}$ & $5.22^{\mathrm{a}}$ & $12.3^{\mathrm{a}}$ & $47.1^{\mathrm{b}}$ \\
\hline & 50 & $36.6^{\mathrm{b}}$ & $3.03^{\mathrm{a}}$ & $5.46^{\mathrm{a}}$ & $14.3^{\mathrm{a}}$ & $46.1^{\mathrm{b}}$ \\
\hline & 60 & $40.3^{\mathrm{a}}$ & $1.86^{\mathrm{b}}$ & $4.76^{\mathrm{b}}$ & $8.52^{\mathrm{b}}$ & $49.3^{\mathrm{a}}$ \\
\hline \multirow{3}{*}{ August } & 40 & 35.9 & $3.51^{\mathrm{a}}$ & 5.37 & 13.1 & 47.5 \\
\hline & 50 & 36.6 & $3.37^{\mathrm{a}}$ & 5.09 & 10.5 & 49.5 \\
\hline & 60 & 37.2 & $2.36^{\mathrm{b}}$ & 5.26 & 12.0 & 48.4 \\
\hline \multirow{3}{*}{ September } & 40 & $35.0^{\mathrm{b}}$ & $3.92^{\mathrm{a}}$ & $5.36^{\mathrm{a}}$ & $12.6^{\mathrm{a}}$ & $48.4^{\mathrm{b}}$ \\
\hline & 50 & $36.2^{\mathrm{b}}$ & $3.28^{\mathrm{a}}$ & $5.42^{\mathrm{a}}$ & $13.7^{\mathrm{a}}$ & $46.8^{\mathrm{b}}$ \\
\hline & 60 & $40.7^{\mathrm{a}}$ & $1.86^{\mathrm{b}}$ & $4.52^{\mathrm{b}}$ & $6.18^{\mathrm{b}}$ & $51.3^{\mathrm{a}}$ \\
\hline \multirow{3}{*}{ October } & 40 & 36.7 & $4.26^{\mathrm{a}}$ & 5.07 & 10.9 & 48.2 \\
\hline & 50 & 37.6 & $2.80^{\mathrm{b}}$ & 5.30 & 13.1 & 46.4 \\
\hline & 60 & 38.6 & $2.80^{\mathrm{b}}$ & 5.03 & 10.8 & 47.8 \\
\hline SEM & & 0.77 & 0.297 & 0.13 & 1.07 & 0.82 \\
\hline
\end{tabular}


between the sizes of crab were greatest for the first three months, after which differences due to size were no longer apparent for the ash, total nitrogen and estimated protein contents, but remained for the lipid content. Overall, the groups of crabs sized 40 - $50 \mathrm{~mm}$ and 50 $60 \mathrm{~mm}$ were similar in composition, while the larger crabs, sized 60 - $70 \mathrm{~mm}$, tended to have higher ash and lower lipid and total nitrogen levels. Differences in the estimated chitin levels were most pronounced in June, July, and September only. Generally, the proportions of total nitrogen, estimated true protein and lipid were greatest in May, after which they remained relatively constant.

\subsection{Assessment of Harvestable Populations}

The eastern shore of PEI had the highest green crab concentration (up to $32 \mathrm{crabs} / \mathrm{trap} / \mathrm{d}$ ) (Figure 1). Although sampling was only conducted on the western part of the south shore, the catches were higher there than those on the north shore, but lower than those on the eastern shore (Figure 1).

\section{DISCUSSION}

The chemical composition of whole green crab sampled from estuaries in eastern PEI (May to October 2012) suggests that the size of the crabs affects the protein and fat content more than the month of catch. The larger crabs had higher levels of ash and lower levels of nitrogen and lipid in the first half of the season. These results may suggest the larger crabs had recently moulted and had a relatively higher proportion of shell compared to the smaller crabs, which are consistent with the corresponding estimated chitin content (Table 1). The chemical composition, especially fat content, is dependent on food type and availability [12] and this may vary over the course of the fishing season.

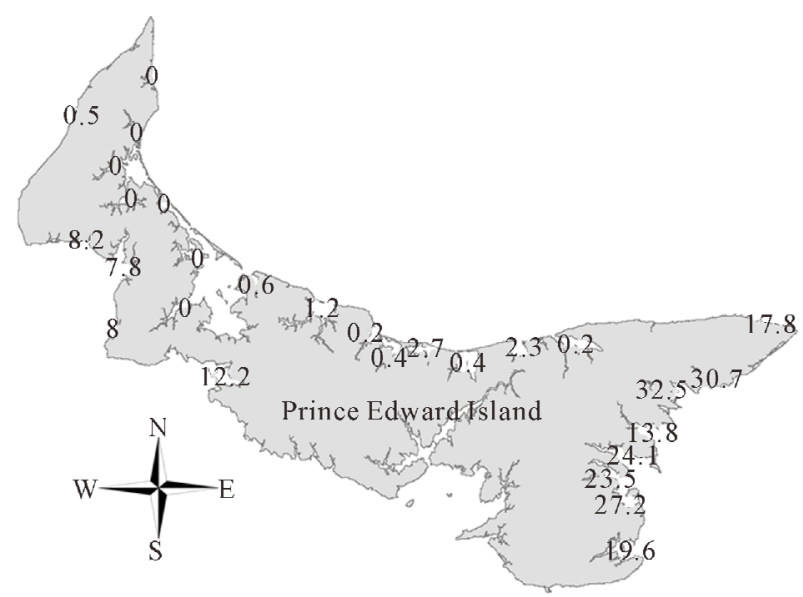

Figure 1. Green crab daily catch rates (number of crabs/trap/ day) based on three day sampling period for PEI in 2012.
Regardless of the month or size of crab sampled in our study, the whole crab was generally high in ash and protein, and low in fat. For most animal feeds, with the possible exception of poultry feeds, the high ash content of whole crab may be a limiting factor for use as a primary feed ingredient. However, the whole crab may be suitable for human consumption as nutrient concentration is less of a concern.

Our assessment of the distribution of green crab and historical records available [17] suggest that there has been a large increase in the number of crabs since 1999 . In that year, less than one crab per trap per day was collected in eastern PEI [17]. Using similar gear and techniques, this area is now estimated to have daily catch rates up to 32 crabs per trap per day. Considering that the initial invasion of green crabs was detected in this particular area (Georgetown, PE), our results suggest that these are well established and still growing populations. The southern shore of PEI appears to have fewer crabs, but could still contribute to a commercial fishery. Recent monitoring of population numbers in the two largest embayments of this area (Hillsborough and Bedeque systems) [4] suggests that these populations are increasing in numbers and spreading into areas not previously colonized. Given the change between 1999 and 2012 in crab numbers on PEI, and the increase in crabs observed in other areas of the Canadian Maritime region $[2,18]$, we anticipate that crab numbers in western and northern PEI, currently less than one crab per trap per day, will also increase.

The relatively constant chemical composition during the six-month fishing season suggests that there is no ideal time to fish green crab. This makes it possible to schedule a green crab fishery at a time when seafood processing plants are idle. However, it may be beneficial to establish a fishery that enables the removal of some green crabs earlier in the season before they propagate or moult. This may maximize the yield of protein and lipid in crab products and reduce the impact of the crabs on the environment.

In conclusion, there is a large quantity of green crab on PEI, particularly along the east coast. The chemical analysis suggests that whole crab is high in protein and low in fat. Also, although there were small differences in protein and fat content over time and by size of crab, chemical composition can be considered relatively consistent in terms of quality. The whole product is high in ash, which may limit its utility in some animal feeds, but may be beneficial for human-grade products such as flavourings for seafood soups, dips and sauces.

\section{ACKNOWLEDGEMENTS}

We would like to thank Cassandra Mellish and Paula Tumon-Flynn and the PEI Shellfish Association for their help with the collection of 
green crabs. This project was funded by an Innovation PEI Pilot and Discovery Grant (2012).

\section{REFERENCES}

[1] Audet, D., Davis, D.S., Miron, G., Moriyasu, M., Benhalima and Campbell. K.R. (2003) Geographical expansion of a nonindigenous crab, Carcinusmaenas (L.), along the Nova Scotian shore into the southeastern Gulf of St. Lawrence, Canada. Journal of Shellfish Research, 22, 255-262.

[2] Klassen, G. and Locke. A. (2007) A biological synopsis of the European green crab, Carcinusmaenas. Canadian Manuscript Report of Fisheries and Aquatic Sciences No. 2818.

[3] Baeta, A., Cabral, H.N., Marques, J.C. and Pardal, M.A. (2006) Feeding ecology of the green crab, Carcinusmaenas (L. 1758) in a temperate estuary, Portugal. Crustaceana, 79, 1181-1193. http://dx.doi.org/10.1163/156854006778859506

[4] Pickering, T. and Quijon, P.A. (2011) Potential effects of a non-indigenous predator in its expanded range: Assessing green crab, Carcinusmaenas (Linnaeus), prey preference in a productive shellfish are of Atlantic Canada. Marine Biology, 158, 2065-2078. http://dx.doi.org/10.1007/s00227-011-1713-8

[5] Matheson, K., Gagnon, P. (2012) Effects of temperature, body size, and chelae loss on competition for a limited food resource between indigenous rock crab (Cancer irroratus Say) and recently introduced green crab (Carcinusmaenas). Journal of Experimental Marine Biology and Ecology, 428, 49-56.

http://dx.doi.org/10.1016/j.jembe.2012.06.003

[6] Rossong, M.A., Quijon, P.A., Williams, P.J. and Snelgrove, P.V.R. (2011) Foraging and shelter behaviour of juvenile American lobster (Homarusamericanus): The influence of a non-indigenous crab. Journal of Experimental Marine Biology and Ecology, 403, 75-80. http://dx.doi.org/10.1016/j.jembe.2011.04.008

[7] Davis, R.C., Short, F.T. and Burdick, D.M. (1998) Quantifying the effects of green crab damage to eelgrass transplants. Restoration Ecology, 6, 297-302. http://dx.doi.org/10.1046/j.1526-100X.1998.00634.x

[8] Malyshev, A. and Quijon, P.A. (2011) Disruption of essential habitat by a coastal invader: New evidence of green crab effects on eelgrass beds. ICES Journal of Marine Science, 68, 1852-1856.

http://dx.doi.org/10.1093/icesjms/fsr126

[9] Rogers, R. (2001) The green menace: The European green crab. Environmental Practice, 3, 93-95. http://dx.doi.org/10.1017/S1466046600002258

[10] Galetti, J.A. (2010) Mechanical processing of European green crab (Carcinusmaenas), the development of a value-added product and the use of restructuring additives to increase the functional properties of green crab patties. M.Sc. Thesis. University of Maine, $140 \mathrm{p}$.

[11] Lafferty, K.D. and Kuris, A.M. (1996) Biological control of marine pests. Ecology, 77, 1989-2000. http://dx.doi.org/10.2307/2265695

[12] Oliveira, G.T., Fernandes, F.A., Bueno, A.A.P., BondBuckup. G. (2007) Seasonal variations in the intermediate metabolism of Aeglaplatensis (Crustacea, Aeglidae). Comparative Biochemistry and Physiology-Part A, 147, 600-606. http://dx.doi.org/10.1016/j.cbpa.2006.08.025

[13] Souchet, N. and Laplante, S. (2007) Seasonal and geographical variations of sterol composition in snow crab hepatopancreas and pelagic fish viscera from Eastern Quebec. Comparative Biochemistry and PhysiologyPart B, 147, 378-386. http://dx.doi.org/10.1016/j.cbpb.2007.02.001

[14] AOAC International (2007) Official methods of analysis. 18th Edition, Associations of Analytical Chemists, International, Washington DC.

[15] Diaz-Rojas, E.I., Arguelles-Monal, W.M., Higuera-Ciapara, I., Hernandez, J., Lizardi-Mendoza, J. and Goycoolea, F.M. (2006) Determination of chitin and protein contents during the isolation of chitin from shrimp waste. Macromolecular Bioscience, 6, 340-347. http://dx.doi.org/10.1002/mabi.200500233

[16] SAS. (2004) SAS/STAT user's guide. Version 9.1, SAS Institute Incorporated, Cary NC.

[17] Gillis, D.J., MacPherson, J.N. and Rattray, T.T. (2000) The status of the green crab (Carcinusmaenas) in Prince Edward Island in 1999. PEI Department of Fisheries \& Tourism, Fisheries \& Aquaculture Division, Report 255.

[18] Miron G., Audet, D., Landry, T. and Moriyasu, M. (2005) Predation potential of the invasive green crab (Carcinusmaenas) and other common predators on commercial bivalve species found on Prince Edward Island. Journal of Shellfish Research, 24, 578-586. 